\title{
SEMIOTIC ANALYSIS OF THE POLITICAL COMMUNICATION PATTERNS OF JOKO WIDODO AND NAHDLATUL ULAMA IN THE 2019 PRESIDENTIAL ELECTION CAMPAIGN
}

\author{
By \\ Achmad Nafhis Ubaydillah ${ }^{1}$, Effy Zalfiana Rusfian ${ }^{2}$ \\ ${ }^{1}$ Communication Science - Faculty of Social and Political Sciences, University of Indonesia \\ ${ }^{2}$ Faculty of Administrative Science, University of Indonesia \\ Email : ${ }^{1}$ achmad.nafhis01@ui.ac.id, ${ }^{2}$ effy.zalfiana@ui.ac.id
}

\begin{abstract}
Article Info
Article History:

Received:12-10-21

Revised : 18-11-21

Accepted: 26-11-2021

ABSTRACT

Semiotics is used as the basis for the meaning contained in each message, especially regarding political communication which uses a reference that every message meaning is contained in it. A political communication that uses the interactional communication model carried out by Joko Widodo and Nahdlatul Ulama convinces the public to support Joko Widodo as a candidate for President of Indonesia in 2019. Semiotics has a relationship with the prevailing culture in an area due to signs and patterns of political communication. carried out by Joko Widodo and Nahdlatul

Keywords:

Semiotics, Political

Communication, Meaning,

Message, Joko Widodo,

Nahdlatul Ulama

Ulama is believed to be a communication process and uses signs and figures of speech through the metaphor of political communication by referring to the communication made between the two actors to participate in seeing the communication process by sending messages to the public. Semiotics is used in a message as well as to be sent to the public. The campaign carried out by Joko Widodo has a close relationship with Nahdlatul Ulama as the two of them did to believe in all Indonesian people with the messages sent by both of them. However, the semiotic element contained in the political communication carried out by Joko Widodo and Nahdlatul Ulama invites the Indonesian people to follow what is done by interpreting the meaning of semiotics in the political messages sent by Joko Widodo and Nahdlatul Ulama to the Indonesian people.
\end{abstract}

Thisisan open accessarticleundertheCC BY-SAlicense.

CorrespondingAuthor:

Achmad Nafhis Ubaydillah, S.H.Int.

Communication Science - Faculty of Social and Political Sciences,

University of Indonesia,

Email: achmad.nafhis01@ui.ac.id

\section{INTRODUCTION}

In 2019 Indonesia has a people's party, namely a democratic party where the Indonesian people can voluntarily choose a presidential candidate who will lead the Indonesian state for a period of 5 years. This is believed to also have a good impact on the democratic climate of the Indonesian state because the people's voice is very important in the process of the presidential election democratic party which can make the aspirations of the people conveyed to the presidential candidate to be elected. People are happy because they can contribute by choosing their leaders. There is no exception for people who actively support the presidential candidate Joko Widodo who is believed to be the winner of the candidate in the political democracy party for the presidential election of the Republic of Indonesia for the period 2019 - 2024. Joko Widodo himself had previously served as President of the Republic of Indonesia in the period $2014-2019$. However, development and also the unfinished vision and mission of President Joko Widodo and is believed to be the voice of the people to want Joko Widodo to run again in the 2019-2024 Indonesian presidential election, making the campaign team from Joko Widodo look for ways to increase Joko Widodo's popularity in winning the presidency again in the period second. 
Joko Widodo does have a good legacy in his leadership in his first term as President of the Republic of Indonesia. This can be seen from the rapid and massive increase in infrastructure and economic development, especially in increasing state income which aims to raise the standard of living for the welfare of the Indonesian people. People from the regions also look enthusiastic and also believe in Joko Widodo because in his leadership as President of Indonesia all infrastructure resources have been spread to each community area in the region even to remote territories in regional areas in Indonesia. Therefore, the people in the regions of Indonesia also feel the benefits of the development carried out by Joko Widodo. No exception in the socio-cultural field, the integration and harmony of economic infrastructure development makes the regions in Indonesia increase their harmony. So that it makes it easy to increase Joko Widodo's popularity in the presidential campaign of the Republic of Indonesia in 2019.

Joko Widodo is aware that the vision and mission that he created in the first period need to be improved because development development is not enough to win the Indonesian presidential election. Other methods need to be needed to win the hearts of the people, especially the opposing pair, namely Prabowo Subianto who collaborated with SandiagaSalahudin Uno. Sandiaga Uno as a successful entrepreneur in Indonesia. Therefore, Joko Widodo has another campaign strategy to be able to attract the voices of the Indonesian people in electing him to be President of the Republic of Indonesia again in the second period. The campaign strategy was carried out by the campaign team from Joko Widodo to attract the sympathy of the Indonesian people, especially in the first period there was a lot of news related to Joko Widodo who did not embrace Muslims in running his government as President. It can be seen from the number of regions related to social, political, and legal issues that often spread and even ignite sparks of public anger, especially related to the phenomenon of riots in the regions.

The campaign strategy carried out by Joko Widodo's winning team in the second period was more social, mental, and religious in nature where Joko Widodo was looking for a figure who could improve the image of Joko Widodo's religiosity to accompany him as Vice President who was paired with Joko Widodo presidential candidate. As well as other ways to attract sympathy from the community, especially the Muslim community so that they can choose Joko Widodo in the 2019 presidential election. Joko Widodo, who has a business background and comes from Solo, is very close to the Nahdlatul Ulama organization and is also close to K.H. Abdurahman Wahid (4th President of Indonesia). Moreover, Joko Widodo has argued several times that he feels comfortable with Kiai NU. He said this on the 93rd birthday of Nahdlatul Ulama. This statement is believed to be a symbol that Joko Widodo is close to the Muslim organization Nahdlatul Ulama. In this regard, Joko Widodo really needs voices from the Muslim community, especially when he was previously Governor of DKI Jakarta and Deputy Governor of DKI Jakarta, namely Basuki Tjahaja Purnama or commonly known as Ahok, became a separate symbol that Joko Widodo was paired with figures from minority groups. and was elected as Governor and Deputy Governor of DKI Jakarta.

Joko Widodo does need a voice from Muslims, therefore the campaign strategy carried out by Joko Widodo's campaign team in the 2019 presidential election is believed to be a process of change and he also made a jargon in his campaign, namely mental revolution. In contrast to the 2014 presidential election when Joko Widodo made the campaign jargon, namely work, work, work. This is because the progress of development that has been very visible in the period of Joko Widodo's leadership, but the existence of public lies where Joko Widodo seems far from Muslims must be strongly resisted and even have to fight the information for the campaign strategy that he carried out in the contestation of the Indonesian presidential election. for the period $2019-2024$. Political acrobatics can also be seen from the news clips related to information about Joko Widodo's policies that are more inclined to the public from businessmen and conglomerates. Meanwhile, the Indonesian people, which in fact consist of Muslim majority groups and middle-income groups, are very sensitive regarding businessmen and conglomerates because only a few of the percentage of Indonesian society as a whole are included in the class category of entrepreneurs and conglomerates. Therefore, the voice of the Muslims is very influential because most of the Indonesian people who are Muslim make this a potential for presidential candidates who take part in the presidential election.

Moreover, in Indonesia itself, there is the largest Muslim organization that oversees and has branches spread across various regions in Indonesia and has a strong voice and sympathizer base that can be a factor or key in winning a campaign through a strategy that can win the heart of the organization. The organization is named Nahdlatul Ulama which does have a strong base of sympathizers and is spread in various areas where it has the biggest key in the East Java area. The province of East Java itself is the basis for the voice of strong sympathizers in the voice of the Nahdlatul Ulama organization and has community characteristics that tend to be one voice if the top leadership in the organization has made a choice for the Nahdlatul Ulama organization to make its choice even though it is not openly or in words. another in an explicit form. So with Joko Widodo's background in the 2019 Presidential election campaign and the Nahdlatul Ulama organization, this is a factor that can win the hearts of the people from Muslims to win the Indonesian presidential election contestation in 2019. 
International Journal of Social Science (IJSS)

Vol.1 Issue.4 December 2021, pp: 453-460

ISSN: 2798-3463 (Printed) | 2798-4079 (Online)

DOI:https://doi.org/10.53625/ijss.v1i4.737

\section{Research Problems}

Is Joko Widodo's political campaign strategy in attracting the sympathy of Muslims through Nahdlatul Ulama effective in increasing Joko Widodo's popularity in the contestation of the Presidential Election of the Republic of Indonesia in 2019.

\section{Research purposes}

Analyzing the political communication patterns of Joko Widodo and Nahdlatul Ulama in winning the political campaign of Joko Widodo in the 2019 presidential election of the Republic of Indonesia.

\section{THEORETICAL FRAMEWORK}

\subsection{Political Communication}

Political communication is a means for actors participating in general elections or democratic parties held in a country. This underlies that the communication patterns carried out are also aimed at gaining sympathy and attracting attention from the wider community, especially to be able to vote according to political messages sent from actors participating in general election contestations to the wider community. Basically political communication contains that communication is when sending messages to the public the terms of the political nuances in it, giving rise to forms of sending messages that contain elements of invitation and are mainly political to be able to influence the community. Political communication is used to gain influence or in other cases power that can invite people to vote in elections and support political actors when participating in the contestation of democratic parties in a country.

Political communication during the 1960s era previously used pamphlets, leaflets, and other media as a means of channeling suggestions, criticisms, and aspirations to the ruling government. Meanwhile, at this time the phenomenon of political communication media has changed to using conventional media, namely using media intermediaries using electronic devices such as print media, radio, television, internet, and other media that can disseminate information quickly (Jerry Indrawan, Efriza, Anwar Ilmar, 2020). Political communication does have a political nature and it is indeed used as a way by politicians to get people's attention.

\subsection{Interactional Model of Political Communication}

Communication plays a very important role, especially in matters that contain elements of political content, in this case being political communication that can be used by political figures or candidates who participate in both legislative elections, legislative elections, or figures who can have a strong influence on the statements issued by him. to the public. Especially in the figures who participated in the presidential election where every step taken by the candidate was instantly covered by the media and it is not uncommon for steps or activities that can create an image of themselves that will decrease in the prestige of their electability. In political communication itself, campaigning can be interpreted as a method, but it is used in various ways so that the delivery given to the public will enter their minds and they will follow the invitation campaigned by certain candidates to be able to vote for them in the general election conducted. As done by political figures in attracting the public to be able to vote for themselves using various platforms either directly or indirectly in order to gain public trust to be able to win the presidential election in this study, namely Joko Widodo in attracting the public to vote for him.

As in political communication using an interactional model where political figures when speaking convey messages, he uses implied forms of messages. By using the interpretation of the implied message, the political figure is believed to be using a form of communication that can be interpreted by the people who see or hear it. Gesture patterns and closeness in message delivery activities were also identified as a form of passive interactional model of political communication. The meaning carried out by the community can be seen by the spectacle shown by political figures in this case to the public.

No exception with other subjects who received responses from political figures in this case the Nahdlatul Ulama organization reiterated its response to several messages issued by Joko Widodo when conducting a campaign to capture Muslim votes to be able to win the contestation of the Presidential Election of the Republic of Indonesia in 2019. Nahdlatul Ulama and Joko Widodo indeed, if we look at the statements in the media, this makes this a kind of interactional communication model. The two subjects who send messages to each other but are implied have meanings contained in them to establish a relationship by having mutual attachment to become a unity that Nahdlatul Ulama and Joko Widodo have the same commitment where it can be useful for Joko Widodo to get votes from the majority Muslims, especially from the Nahdlatul Ulama organization which incidentally became the largest Muslim organization in Indonesia.

\subsection{Political Communication Metaphor}

Metaphor is a technique commonly used in grammar and communication which is usually used to make everything that is said and likened by the communicator to the recipient of the message. Metaphors themselves are closely related in political communication because a parable and a utopian sense as well as expectations that the 
community wants can be used by communicators to be able to take sympathy and empathy from the community, especially during the campaign period in order to get the attention of public sympathy to be able to choose according to the messages conveyed. into the recesses of the public's heart on the basis of the campaign carried out by the communicator. The languages used can also be adjusted by the communicator to be able to make the message enter and have emotional attachments and feelings both in terms of delivery, message tone, message conveyed words, gestures, and other things that can show the public that the communicator does have sympathy. and empathy for the community to be able to feel the same and will be fought for if elected in the contestation of the campaign event being carried out.

Metaphors themselves are very important to be used to be able to elaborate on the messages sent by communicators and in this case the campaign strategies carried out by Joko Widodo and also Nahdlatul Ulama both have the properties of messages that contain metaphorical content in their communication when speaking in front of the public. In particular, there are so many messages that contain metaphors where it becomes a joke but contains a very strong element of meaning that between Joko Widodo and Nahdlatul Ulama both are like a couple who have political romance and influence for both of them. Metaphor is actually a classic method used by political communication orators, especially in campaigning messages so that the people who receive the message will be touched by the recesses of their hearts. Moreover, the communication carried out by Joko Widodo often contains elements of the Islamic organization Nahdlatul Ulama, especially during the 93rd Birthday of NU in Jakarta in 2019 where at that time Joko Widodo said that he was very close and peaceful when he felt close to the Nahdlatul Ulama kiai. Suddenly the statement contains elements of a very large political content. The reason is that this can be used as a political message to the Indonesian people, especially during the 2019 Presidential campaign and Joko Widodo's status as President of the Republic of Indonesia, strengthening close relations with Nahdlatul Ulama and cooperating directly with the message implied by Joko Widodo and Nahdlatul. Ulama to the Indonesian people.

As well as from the Nahdlatul Ulama organization itself, they often make statements that they support what Joko Widodo has done while serving as President and ahead of the political year in 2019, the strategy carried out by Nahdlatul Ulama also has maneuvers to attract supporters' votes - supporters and followers of the Nahdlatul Ulama organization to be able to elect Joko Widodo and become supporters of Joko Widodo's campaign to win the presidential election in 2019. This underlies that metaphors are used mainly related to political communication carried out by both Joko Widodo and Nahdlatul Ulama to be able to send messages to the public at large, especially related to its introduction and invite the public to be able to make choices according to the intent of the use of the metaphor. This is believed to be a means of making implications in communication that contains certain political intentions and meanings to the community.

\subsection{Semiotics}

Semiotics is defined as a discipline that has meaning and signs on objects and meanings. According to Zoest, things are unlimited and can be interpreted from signs that have certain meanings and elements (Zoest, 1993). Language that has the intrigue of something and the elements that contain meaning in it becomes a social phenomenon (Piliang, 2004). Epistemologically semiotics has a certain level which according to Ferdinand de Saussure has a relationship between langue and parole. Saussure explained that signs and signs have implications between the two because a communication that has meaning both explicitly and implicitly has a certain sign in its communication made by the communicator to the communicant. According to Roland Barthes, signs are influenced and affect reality and culture. This is because the value, culture, and meaning of the connotation and denotation of sentences are influenced by the culture of a particular area or place which allows semiotics to be the interpretation of each subject differently from individual to individual (Mas'udMuhammadiah, Muliadi, Andi Hamsiah, 2020) .

Dan Nimmo said that identification in terms of semiotics which has elements of political meaning can be used as an illustration that voters can judge from verbal communication made by the subject and informed to the public through media intermediaries (Nimmo, 2000). A core of communication carried out by political actors in it has an invitation or information that contains that he is the best and has a target and mission to be able to convince the public against him. Although semiotics has nuances that have context in it, people sometimes have different meanings, but the addition of the media to add meaning in disseminating information and influencing people's mindsets. The interpretation of textual news and public understanding of existing political communication makes people interpret the interpretation of political communication by political figures who participate in election candidates both on the scale of becoming Head of State, Head of Region, and other state officials elected by a democratic mechanism. and elected by the people.

\section{METHODS}

This research paradigm uses the positivism paradigm which refers to social reality that is empirical and can be tested for validity based on scientific principles. It is believed that research that uses scientific principles as a 
International Journal of Social Science (IJSS)

Vol.1 Issue.4 December 2021, pp: 453-460

ISSN: 2798-3463 (Printed) | 2798-4079 (Online)

DOI:https://doi.org/10.53625/ijss.v1i4.737

basic reference in making research will have objectivity that greatly affects the sources and databases that will be tested and discussed in this study. The levels in research problems and databases in the theoretical basis allow researchers to bring theoretical foundations as the basis for processing data which will later be used as research results that have verification that has a high objective level. According to Auguste Comte, an independent science must be able to explain facts that must be logical and can be tested empirically (Morissan, 2019).

Qualitative research methods are based on research that refers to the process of reviewing the literature and sources of data that can be processed and traced for truth. The qualitative research uses a method where the problems can be described and addressed to the data sources in detail and thoroughly in the data processing process in this study. Qualitative methods will strengthen the information contained in the research problem and collect data directly due to citing data or the words of the subject either directly or indirectly involved which has implications for research questions and problems (J. David Creswell \& John W. Creswell, 2017). This research method uses research used in data collection based on literature studies and other things that can enrich useful information in research and examine the object of research problems by looking at the clarity of sources that have been obtained and then processed in research.

As in the qualitative method using sources and literature review which allows the data obtained to be studied thoroughly and in detail to get the essence of the research and use text content analysis to see the semiotics of the political communication patterns of Joko Widodo and Nahdlatul Ulama in the 2019 Presidential election campaign.

\section{RESULTS AND DISCUSSION}

Semiotics is used in analyzing a context of meaning of words that are in a sentence or picture that is displayed to the public. It is used because a message of meaning that is informative and communicative has a message that must be conveyed to the communicant. A political action or event also has its own meaning because there is a message addressed to the public to participate in the success of the agenda owned by political actors by interpreting the messages stored in the communication that political actors do to the community. A picture of political actors who have elements of semiotic meaning in their political service campaign advertisements to the public triggers a meaning for messages received by the community. A semiotic meaning as done by Joko Widodo and Nahdlatul Ulama has the meaning that both of them have written language that seems to invite Nahdliyin and supporters of Joko Widodo in the 2019 Presidential Election campaign to invite each other and have persuasive maneuvers for the Indonesian people to participate in supporting Joko Widodo as a candidate for President of the Republic of Indonesia 2019-2024 (Handayani, 2021).

Joko Widodo and Nahdlatul Ulama, who share a common ideology, have the understanding that both have implications for sending messages that are very political in nature and this includes the communication of interactional political communication models between the two, which will later spread the understanding of sending messages to the public so that they get attention. both to the NU organization and also to Joko Widodo ahead of the 2019 Presidential election (Safitri, 2019). The meaning of semiotics can be used as a commodity in political communication. The political nuance in describing the meaning of the text, political actions from both the NU organization and from Joko Widodo characterize it as having meaning for observers and communication experts who consider that these events are aimed at attracting public sympathy and gaining gain from the nahdliyin. In addition, after the incident that triggered a large-scale demonstration in 2017 during the election for the Governor of DKI where there was a candidate who made a sentence and made a speech that offended a certain religion. So it is no doubt that the political communication carried out by Joko Widodo and Nahdlatul Ulama to secure the position behind the political escalation in Indonesia by using the meanings of texts that can be identified that Joko Widodo and Nahdlatul Ulama have the same vision and mission to the community (Riki Ronaldo \&Darmaiza, 2021).

According to John Fiske (Fiske, 2012) semiotics has three studies, namely the sign itself and has implications for how humans use the sign, a study system that is rooted in culture how to interpret the meaning of the messages contained in it, culture and the use of signs in a culture. message. A meaning contained in the message has a huge impact on society. The reason is that the messages sent by Joko Widodo and Nahdlatul Ulama must reach all circles and can be a response to the aspirations of the Indonesian people due to the uproar in 2017 that caused polarization among the people in Indonesia (FathulQorib\& Mohammad Saleh, 2020).

The meaning contained became a symbol between Joko Widodo and Nahdlatul Ulama because Nahdlatul Ulama who spoke to invite the Nahdliyin to choose Joko Widodo as a candidate for President of Indonesia within a period of five years made it an indication of the existence of meaning in inviting the public, especially the Nahdliyin who really in fact they as social organizations should be neutral and impartial to one side. In relation to the meaning of semiotic analysis associated with political communication, there is a perception that political actors and political 
subjects have a qualified campaign strategy. Because every symbol, event, or meeting between political actors and subjects or things that can boost its popularity makes it the meaning of the political content in it.

The use of mass media is also used as a tool in disseminating message values that contain the meaning of political semiotics to the public. In this way, the community can absorb the messages contained in it so that people will slowly follow the meaning contained in it. The analysis of the campaign model used by using the semiotic meaning structure is divided into eight important things, namely, Intended Effect, Competiting Communication, Communication Object, Target Population \& Receiving Group, The Channel, The Message, The Communicator, \& The Obtained Effect. What is done with eight important things in the campaign all of which have a close relationship with semiotics because the message contained and tucked away with the value of political content must be studied properly regarding the object, the effect caused, the target population of the recipient of the message, the message channel, the content of the message, and the rivals of the target audience. political actors who maneuver other campaigns.

A meaning of semiotics if pulled back must look at the background of the content of the political content of the meaning that is inserted in it to the community. And in this study, which examines Joko Widodo and Nahdlatul Ulama, both of whom communicate interactional models between the two and send messages that have a political impact on the community. The visits made by Joko Widodo during his tenure as President in $2014-2019$, he often visited Islamic boarding schools in the East Java area. The Islamic boarding schools located in East Java that Joko Widodo frequently visited were those that had an affiliation with Nahdlatul Ulama. And the climax ahead of the 2019 presidential election, Joko Widodo intensively went directly to the field and visited Islamic boarding schools, most of which were affiliated and had ties to Nahdlatul Ulama as a mouthpiece in securing votes and attracting a mass base by referring to the location of the pesantren supported by Nahdlatul Ulama.

By looking at the semiotic analysis of Charles Sanders Pierce's model, the signs that were carried out by Joko Widodo and also Nahdlatul Ulama both sent messages to each other with signs so that both of them supported each other in the benefits that both Joko Widodo and Nahdlatul Ulama hoped for a symbiotic relationship of mutualism. both of which benefit. The semotic theory proposed by Charles Sanders Pierce, commonly known as the Grand Theory because of its comprehensive nature and description of the message components in it can be interpreted by the public (Wibowo, 2011). The semiotic meaning of the signs sent by Joko Widodo and Nahdlatul Ulama makes this an indication in inviting the Nahdlatul Ulama community to support Joko Widodo as a presidential candidate in 2019.

The use of metaphors in political communication also contains the meaning of semiotics which means that Joko Widodo and Nahdlatul Ulama both have a specific purpose in their appearance to the public and when sending the message it is shown to the wider community, especially on the political stage both in the national capital and in the location area. pesantren which became the basis for the voice of Nahdlatul Ulama. This is based on the desire to attract the masses with the meaning of messages, both spoken, textual, and movements carried out by Joko Widodo and Nahdlatul Ulama to maneuver when dealing with the public and also the media to send messages in mass and have a political impact to It is widely shown that Joko Widodo and Nahdlatul Ulama are objects and representations of future Indonesian leaders in every campaign or oration they conduct.

By referring to Joko Widodo and Nahdlatul Ulama who carried out massive political communication actions and had political meanings with signs that are believed to be signs for actors who support certain candidates by mobilizing all messages that have political meaning as representations of community organizations that have a mass base The big thing is that by looking at the population of Indonesian people who are members of the Nahdlatul Ulama organization, they have a strong position and make this a position that makes Joko Widodo and Nahdlatul Ulama both become a relationship in attracting sympathy and mass from the Indonesian people and the people who are members of the Nahdlatul organization. Scholars are either active or passive.

\section{CONCLUSION}

From the results of the semiotic analysis, it was found that the signs obtained from the existence of political communication in the campaign carried out before the presidential election in 2019 between Joko Widodo and Nahdlatul Ulama became a very warm interaction due to the meaning of semiotic messages from both Joko Widodo and Nahdlatul Ulama. contains to be able to succeed Joko Widodo to be elected President of the Republic of Indonesia in the period 2019 to 2024. The existence of two-way communication and displayed in front of the public creates belief and interpretation of messages that are captured by the public to be able to support Joko Widodo as a candidate for President of Indonesia 2019 Things that have political meaning in the message element are used as an indication of political communication between the two.

The interactional model of communication is carried out as a way for the public to understand that both Joko Widodo and Nahdlatul Ulama have the meaning of political content in embodiment to the community. In the 
International Journal of Social Science (IJSS)

Vol.1 Issue.4 December 2021, pp: 453-460

ISSN: 2798-3463 (Printed) | 2798-4079 (Online)

DOI:https://doi.org/10.53625/ijss.v1i4.737

end, the public judged that Joko Widodo and Nahdlatul Ulama were to persuade the Indonesian people. The meaning of semiotics becomes a sign that can be used as a political indicator in inviting the Indonesian people to assess that the Nahdliyin are in the niche of Indonesian society to remain confident and support Joko Widodo and attract other people who have good affiliations actively or passive towards Nahdlatul Ulama. Political communication that uses an interactional communication model using the metaphor of political communication as well as the symbols and meanings contained in it become an attractive indicator for the public to understand that in every political actor who participates in a democratic arena agenda. So at every opportunity in sending messages to the public, there are elements inherent in it.

Semiotics is indeed an interpretation for people who see it and receive messages sent by communicators. Communicators must understand correctly to believe that the message contained in it when conducting a campaign has major implications and influences for the community.

\section{REFERENCE}

[1] Fathul Qorib \& Mohammad Saleh. (2020). ANTI ISLAM HINGGA DEKAT EMAK-EMAK: PERANG CITRA JOKOWI DAN PRABOWO PADA PEMILIHAN PRESIDEN 2019. Jurnal Komunikasi Global, 187-208.

[2] Fiske, J. (2012). Pengantar Ilmu Komunikasi . Jakarta: Rajagrafindo Persada.

[3] Handayani, A. P. (2021). ANALISIS SEMIOTIKA JOHN FISKE PADA IKLAN KAMPANYE PEMILU PRESIDEN 2019 JOKOWI - MA'RUF AMIN DI TELEVISI. SEMIOTIKA, 1-9.

[4] J. David Creswell \& John W. Creswell. (2017). Research Design: Qualitative, Quantitative, and Mixed Methods Approaches. SAGE Publications.

[5] Jerry Indrawan, Efriza, Anwar Ilmar. (2020). Kehadiran Media Baru (New Media) Dalam Proses Komunikasi Politik. Medium Jurnal Ilmiah Fakultas Ilmu Komunikasi Universitas Islam Riau, 1-17.

[6] Mas'ud Muhammadiah, Muliadi, Andi Hamsiah. (2020). A Semiotic Analysis of Political News Featured in Indonesia Newspapers . International Journal of Innovation, Creativity, and Change, 1627-1640.

[7] Morissan. (2019). Riset Kualitatif. Jakarta: Kencana.

[8] Nimmo, D. (2000). Komunikasi Politik, Khalayak, Efek. Bandung: Remaja Rosdakarya.

[9] Piliang, Y. A. (2004). Semiotika Teks: Sebuah Pendekatan Analisis Teks. MEDIATOR, 189-198.

[10] Riki Ronaldo \& Darmaiza. (2021). Politisasi Agama dan Politik Kebencian pada Pemilu Presiden Indonesia 2019. Indonesian Journal of Religion and Society, 33-48.

[11] Safitri, E. (2019, Januari 31). Detik News. Retrieved from Doakan Jokowi Menang Pilpres 2019, Said Aqil: Ini Bukan Kampanye: https://news.detik.com/berita/d-4408980/doakan-jokowi-menang-pilpres-2019-saidaqil-ini-bukan-kampanye

[12] Wibowo, I. S. (2011). Semiotika Komunikasi. Jakarta: Mitra Wacana Media.

[13] Zoest, A. V. (1993). Semiotika: Tentang Tanda, Cara Kerjanya dan Apa yang Kita Lakukan Dengannya . Jakarta: Yayasan Sumber Agung. 
